\title{
The effect of GABRB3 polymorphisms on brain function and structure in healthy male volunteers assessed by multimodal imaging
}

Citation for published version (APA):

Arrubla Martínez , J. A. (2017). The effect of GABRB3 polymorphisms on brain function and structure in healthy male volunteers assessed by multimodal imaging. [Doctoral Thesis, Maastricht University, Université de Liège]. Maastricht University. https://doi.org/10.26481/dis.20170712jaam

Document status and date:

Published: 01/01/2017

DOI:

10.26481/dis.20170712jaam

Document Version:

Publisher's PDF, also known as Version of record

Please check the document version of this publication:

- A submitted manuscript is the version of the article upon submission and before peer-review. There can be important differences between the submitted version and the official published version of record.

People interested in the research are advised to contact the author for the final version of the publication, or visit the DOI to the publisher's website.

- The final author version and the galley proof are versions of the publication after peer review.

- The final published version features the final layout of the paper including the volume, issue and page numbers.

Link to publication

\footnotetext{
General rights rights.

- You may freely distribute the URL identifying the publication in the public portal. please follow below link for the End User Agreement:

www.umlib.nl/taverne-license

Take down policy

If you believe that this document breaches copyright please contact us at:

repository@maastrichtuniversity.nl

providing details and we will investigate your claim.
}

Copyright and moral rights for the publications made accessible in the public portal are retained by the authors and/or other copyright owners and it is a condition of accessing publications that users recognise and abide by the legal requirements associated with these

- Users may download and print one copy of any publication from the public portal for the purpose of private study or research.

- You may not further distribute the material or use it for any profit-making activity or commercial gain

If the publication is distributed under the terms of Article 25fa of the Dutch Copyright Act, indicated by the "Taverne" license above, 


\section{Abstract}

The combination of genetic information and data provided by magnetic resonance imaging (MRI) techniques is commonly referred as imaging genetics, an interesting approach with the potential to investigate the mechanisms linked to genetic variation. The gene that codifies the beta- 3 subunit of the GABA-A receptor (GABRB3) is of great interest due to its early expression during embryonic stages, its role in neurodevelopment and its relationship with neurologic diseases such as epilepsy and autism. In order to investigate the possible effects of GABRB3 on brain structure and function, a sample of 63 healthy young male volunteers was measured using multimodal imaging techniques including: structural imaging, diffusion-weighted imaging, resting state fMRI, magnetic resonance spectroscopy and electroencephalography (EEG). Inter-group differences in brain function and structure were tested on the basis of frequency and prevalence of G2, the most frequent allele of GABRB3 in the population. The results showed that there were significant differences in diffusion parameters among the different subgroups on the basis of the G2 allelic prevalence and frequency. Noncarrier volunteers exhibited significantly increased axial diffusivity in the right superior longitudinal fasciculus, right corticospinal tract and body of the corpus callosum compared to homozygote carriers of the G2 allele. Initially, such differences in diffusion parameters were only evident for axial diffusivity, although when a focused region-of-interest analysis was performed, differences in fractional anisotropy and mean diffusivity emerged. A statistically significant higher delta voltage in the global activity of EEG was also found in homozygote carriers of the G2 allele compared to heterozygote carries. The results presented here confirm the importance of the expression of GABRB3 gene in brain structure, particularly in defining the features of the white matter microstructure. Differences in EEG were also found to depend on the frequency of the G2 allele, which confirms the conclusions of previous investigations in which the expression of GABRB3 was crucial for the activity of EEG. 